\title{
Biodiesel and the search for a balance between society, environment and healthy
}

\section{Biodiesel e a busca por um equilibrio entre sociedade, meio ambiente e saúde}

Recebimento: 20/04/2020 - Aceite: 20/07/2020 - Publicação: 01/08/2020

Processo de Avaliação: Double Blind Review

Rodrigo Fazani Esteves Sanches

$\mathrm{PhD}$ in Biodiversity and Environment

Instituto de Botânica de São Paulo (IBt/SP)

https://orcid.org/0000-0001-7594-0425

rodrigo.fazani@gmail.com

Mariana Gaspar Negrini Yamashiro

Graduated in Chemistry

Universidade de São Paulo (USP)

https://orcid.org/0000-0001-8003-3440

mari.negrini@gmail.com

Priscila Lima Santos

Graduated in Biological Sciences

Centro Universitário Jorge Amado (Unijorge/BA)

https://orcid.org/0000-0002-3814-9383

bio.priscila3003@gmail.com

José Humberto Machado Tambor ${ }^{1}$

$\mathrm{PhD}$ in Sciences, Universidade de São Paulo (USP)

Núcleo de Pesquisa ENIAC - NUPE, Centro Universitário Eniac (ENIAC)

Faculdades Oswaldo Cruz

https://orcid.org/0000-0001-7266-9983

jose.humberto@eniac.edu.br

\footnotetext{
${ }^{1}$ Corresponding author: Centro Universitário Eniac (ENIAC): Rua Força Pública, 89 Centro, Guarulhos - SP, 07012-030- Brazil.
}

Revista ENIAC Pesquisa, Guarulhos (SP), V.9, n.2, ago.- jan. 2020 


\begin{abstract}
The importance of different energy matrixes in the development process of society is undeniable; however, the consumption of fossil fuels has increased atmospheric pollution and has become a serious threat to the health population. Diesel, even so its use is lower than that of gasoline, has a much more harmful emission profile. Biofuels are a present and efficient alternative in the mitigation of greenhouse gases and particulate matter in substitution of or in the mixture with fossil fuels. Researches show that the systems most affected by this pollution are the respiratory, circulatory, and reproductive. Recent data from the World Health Organization (WHO) show that particulate matter alone is responsible for 7 million deaths worldwide, mainly due to respiratory problems. This study searched the scientific literature for the benefits of biodiesel production and the negative effects caused by air pollution. Biodiesel is capable of substantially reducing gas emissions from incomplete combustion of diesel and with the differential of carbon capture $\left(\mathrm{CO}_{2}\right)$ in the phase of soybean cultivation, the main Brazilian raw material.
\end{abstract}

Keywords: biodiesel; environment; health; pollutants; renewable sources; vegetable oils

\title{
RESUMO
}

É inegável a importância de diferentes matrizes energéticas no processo de desenvolvimento da sociedade, contudo, o consumo de combustíveis fósseis tem aumentado a poluição atmosférica e se tornado uma grave ameaça à saúde da população. O diesel, mesmo que seu uso seja inferior ao da gasolina, possui um perfil de emissões muito mais nocivo. Os biocombustíveis são uma alternativa presente e eficiente na mitigação dos gases do efeito estufa e material particulado na substituição ou na mistura com os combustíveis fósseis. Pesquisas apontam que os sistemas mais afetados pela dessa poluição são os respiratórios, circulatórios e reprodutivos. Dados recentes da Organização Mundial da Saúde (OMS) mostram que somente o material particulado é responsável por 7 milhões de mortes no mundo em função principalmente de problemas respiratórios. O presente estudo pesquisou na literatura científica os benefícios na produção de biodiesel e sua contribuição na mitigação dos efeitos negativos causados pela poluição atmosférica. O biodiesel, é capaz de reduzir substancialmente as emissões de gases provenientes da combustão incompleta do diesel fóssil

Revista ENIAC Pesquisa, Guarulhos (SP), V.9, n.2, ago.- jan. 2020 
e com o diferencial da captura de carbono $\left(\mathrm{CO}_{2}\right)$ na fase do cultivo da soja, principal matéria prima brasileira.

Palavras-chave: biodiesel; fontes renováveis; meio ambiente; óleos vegetais; poluentes; saúde

\section{INTRODUCTION}

It is undeniable the importance of different energy matrixes in the process of development of today's society, allowing technological and intellectual progress, in addition to a better quality of life and social. The use of coal as an energy source opened the door to profound changes in social relations, followed by the use of oil and its derivatives as the main global energy matrix in a scenario that extends to the present day. However, over the past few centuries, the environmental impact of using these fuels has become evident.

The consumption of fossil fuels has increased considerably since the Industrial Revolution. Considering that the greatest demand for transportation fuels is supplied by oil products, their excessive use causes air and water pollution, influencing climate changes. (GÜNAY et al., 2019). Estimating the possibility of the depletion of oil reserves and their reaction in the economy, it is necessary to consider their environmental aspects when pointing out that the burning of fossil fuels is the main cause of the increase in the concentration of greenhouse gases in the atmosphere (RAMOS et al., 2011). In addition to the release of $\mathrm{CO}_{2}$, this pollution is also due to the emission of gases such as $\mathrm{SO}_{\mathrm{x}}, \mathrm{NO}_{\mathrm{x}}$ and $\mathrm{CO}$ (ENCARNAÇÃO, 2008). These provoke a degradation of air quality making it a serious threat to the population, they are classified as acute, temporary or chronic effects, which are permanent, causing damage to visibility, damage to vegetation and public health (MANZOLI, 2009; TESTA, 2015).

The biodiesel use is capable of substantially reducing gas emissions from incomplete combustion of diesel, such as CO. This is because biodiesel contains oxygen atoms in its structure, which facilitate complete combustion and minimize the generation of pollutants (ENCARNAÇÃO, 2008).

In this article we aim to analyze in the scientific literature the negative effects produced by atmospheric pollution affected by fossil fuels and the benefits in biodiesel production.

Revista ENIAC Pesquisa, Guarulhos (SP), V.9, n.2, ago.- jan. 2020 
Considering the fact that air pollution causes impacts on health and the environment, it becomes important to consider the need for solutions that aim at greater control of environmental and social issues caused by human intervention. Search for alternatives to the use of fossil fuels.

\subsection{Brazil and biodiesel}

In Brazil, the Internal Energy Offer (IEO) was 294 million tons of oil equivalent (toe) in 2019 , an increase of $1.4 \%$ when compared to 2018. During this period, renewable sources increased by $2.8 \%$ due to strong increases in sugarcane, wind, solar and biodiesel products. It should be noted that in 2019, the share of renewable sources in the Brazilian energy matrix was $46.1 \%$; against $10.8 \%$ in OECD countries and $14.2 \%$ as a world average (RESENHA ENERGÉTICA BRASILEIRA, 2019). The energy generated in Brazil results from the summation of renewable resources of biomass, hydroelectric power plants, oil and its derivatives, natural gas, mineral coal and uranium (Figure 1).

In 2019, Brazil emitted 406.1 million tons of $\mathrm{CO}_{2}\left(\mathrm{tCO}_{2}\right), 37 \%$ and $40 \%$ lower than the OECD block and the world indicator, respectively. In 2017, $\mathrm{CO}_{2}$ emissions from energy use reached 32.8 billion tons. The United States and China accounting for $43 \%$ of total emissions. Brazil, with 0.43 billion $\mathrm{tCO}_{2}$ in 2017 , accounted for $1.3 \%$ of global emissions (RESENHA ENERGÉTICA BRASILEIRA, 2019). The use of biofuels is a relevant energy alternative from an environmental, economic and social point of view (SALLET; ALVIN, 2011).

Revista ENIAC Pesquisa, Guarulhos (SP), V.9, n.2, ago.- jan. 2020 
Figura 1. Brazilian Internal Energy Offer in 2019.

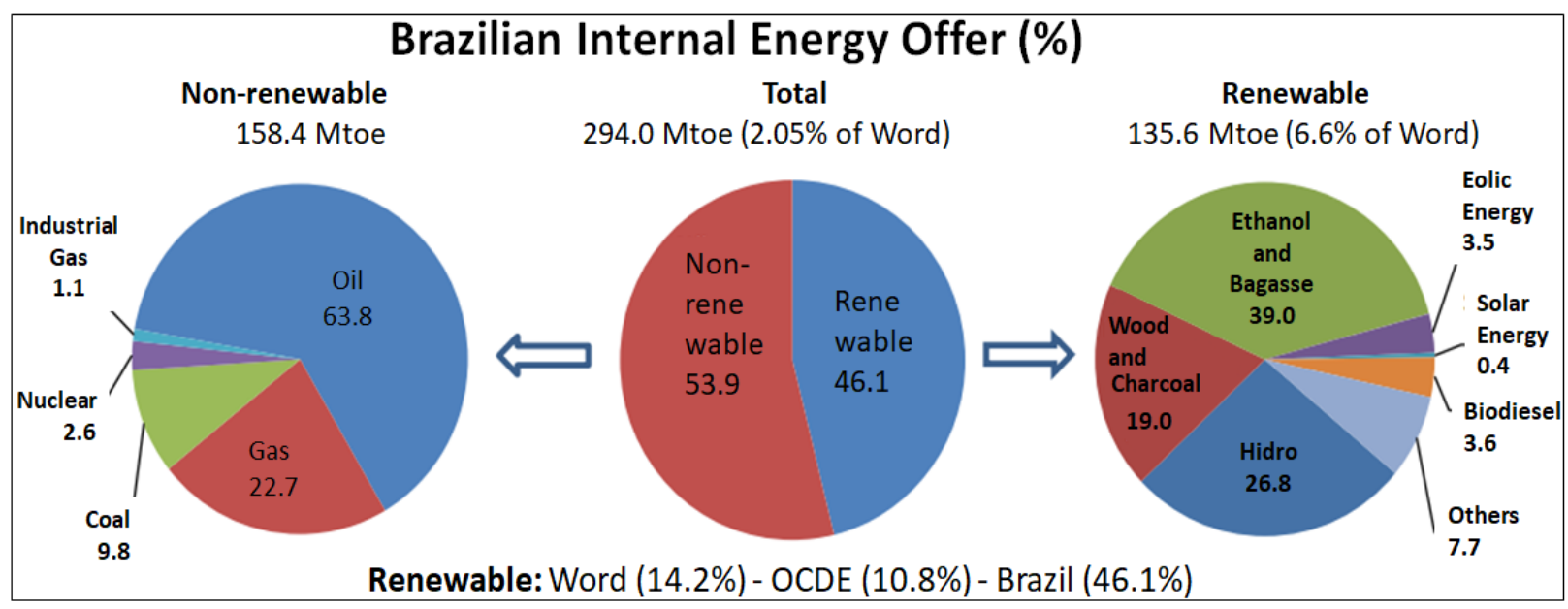

Source: RESENHA ENERGÉTICA BRASILEIRA, 2019.

The use of biofuels in Brazil has increased over the past few years and its share in the National Energy Matrix is expected to grow further. The Brazilian transport sectors mainly use ethanol and biodiesel as biofuels (SALLET; ALVIN, 2011). In 2019, ethanol production was 35.2 million $\mathrm{m}^{3}\left(\mathrm{Mm}^{3}\right)$, showing an increase of 5.6\% over 2018. In addition, biodiesel production was 5,924 thousand $\mathrm{m}^{3}$ in 2019 (Figure 2), with an increase of 10.7\% over 2018, corresponding to $10.3 \%$ of total diesel, or $11.5 \%$ of fossil diesel (RESENHA ENERGÉTICA BRASILEIRA, 2019).

Figure 2. Biodiesel production, by states $\left(\mathrm{mil} \mathrm{m}^{3}\right)$

\begin{tabular}{crrrrrrrrrrrrr}
\hline YEAR & BA & GO & MT & MG & PR & SP & TO & RS & RO & MS & RJ & SC TOTAL \\
\hline 2018 & 376 & 758 & 1.134 & 128 & 597 & 234 & 85 & 1.480 & 16 & 325 & 96 & 122 & 5.350 \\
2019 & 454 & 865 & 1.226 & 131 & 659 & 231 & 92 & 1.630 & 16 & 351 & 138 & 131 & 5.924 \\
$\%$ n $/ n-1$ & 20,7 & 14,1 & 8,1 & 2,5 & 10,4 & $-1,1$ & 8,2 & 10,2 & $-1,9$ & 8,2 & 43,3 & 6,9 & 10,7 \\
$\% n$ & 7,7 & 14,6 & 20,7 & 2,2 & 11,1 & 3,9 & 1,6 & 27,5 & 0,3 & 5,9 & 2,3 & 2,2 & 100,0 \\
\hline
\end{tabular}

Source: RESENHA ENERGÉTICA BRASILEIRA, 2019.

Revista ENIAC Pesquisa, Guarulhos (SP), V.9, n.2, ago.- jan. 2020 
Brazil has already consolidated production and the ethanol industry in a competitive way on the world market, with expressive numbers of production, domestic consumption and fuel exports. On the other hand, the production of biodiesel is more recent and faces an important moment of definitions and overcoming challenges (SALLET; ALVIN, 2011).

Considering that, the World Energy Matrix is predominantly generated by nonrenewable sources, incentives and efforts to produce energy from renewable sources are extremely important. The mandatory addition of a certain percentage of biodiesel to fossil diesel in countries such as the United States, China and Germany stimulates the production and consumption of this renewable source. In Brazil, the implementation of the "Programa Nacional de Uso e Produção do Biodiesel” (PNPB) in 2004, represented important government initiatives for the inclusion of biodiesel as a renewable source for the Brazilian Energy Matrix. However, the continued growth and development of this sector depends on definitions and projections by the Government (SALLET; ALVIN, 2011; SOUZA et al., 2016).

\subsection{Transport and pollution}

Brazil is a predominantly urban country, so most vehicle emissions are concentrated in large urban centers. The different modes of transport interact with the environment and society at various levels: mobility, health, security, economy and employment, in addition to trade and tourism. The transportation of people, consumables and commodities somehow generates air, noise or visual pollution (CARVALHO, 2011). Cargo transportation is important for the development of a society. In Brazil, the transport sector is the one that causes the greatest impact on air quality, with road transport as the main responsible for polluting gas emissions, which mostly uses fossil diesel as fuel (SOLIANI; ARGOUD, 2018).

There are several substances harmful to man and the environment that are released into the atmosphere by motor vehicles, mainly due to the process of burning fossil fuels. Fossil diesel is derived from petroleum and is considered to have a high emission index of particulate material, hydrocarbons and sulfur. Mainly used in compression ignition engines characteristic of the vehicle fleet operating in the road transport mode (SOLIANI; ARGOUD, 2018).

Vehicles powered by fossil diesel emit more $\mathrm{CO}_{2}$ per unit volume compared to the others. Pollutants especially affect the areas of operation of transport. Motorized transport, based on the burning of fossil fuels, is responsible for the emission of various pollutants that

Revista ENIAC Pesquisa, Guarulhos (SP), V.9, n.2, ago.- jan. 2020 
are harmful to health and that degrade the urban environment. In Brazil, large urban centers suffer from excessive pollutants concentration in the atmosphere. Particulate matter emissions are especially important in the environmental monitoring of urban bus lanes. Being heavier, these pollutants do not spread much for atmosphere, being concentrated on the road vicinity (CARVALHO, 2011). A wide range of substances can pollute the air, and the level of pollution or air quality measured by quantification of their toxic substances. Air pollutants are substances that, depending on the concentration, may be inappropriate, harmful or offensive to health and the environment (SPIRO; STIGLIANI, 2009, DERISIO, 2013).

Currently, vehicles used in Brazil emit 106 thousand tons of local pollutants per year in their travels. Buses, followed by automobiles, emit most. As we can see at Figure 3, considering the emission of $\mathrm{CO}_{2} \mathrm{eq}$ (greenhouse gases $\left(\mathrm{CO}_{2}, \mathrm{CH}_{4}\right.$ and $\left.\mathrm{N}_{2} \mathrm{O}\right)$ considered as $\mathrm{CO} 2 \mathrm{eq}$ ), vehicles used by people emit 31 million tons of pollutants per year in their travels. Automobiles, followed by buses, emit most (ANTP, 2018).

Figure 3. Pollutants distribution emitted by vehicles by mode of transport in 2018 .

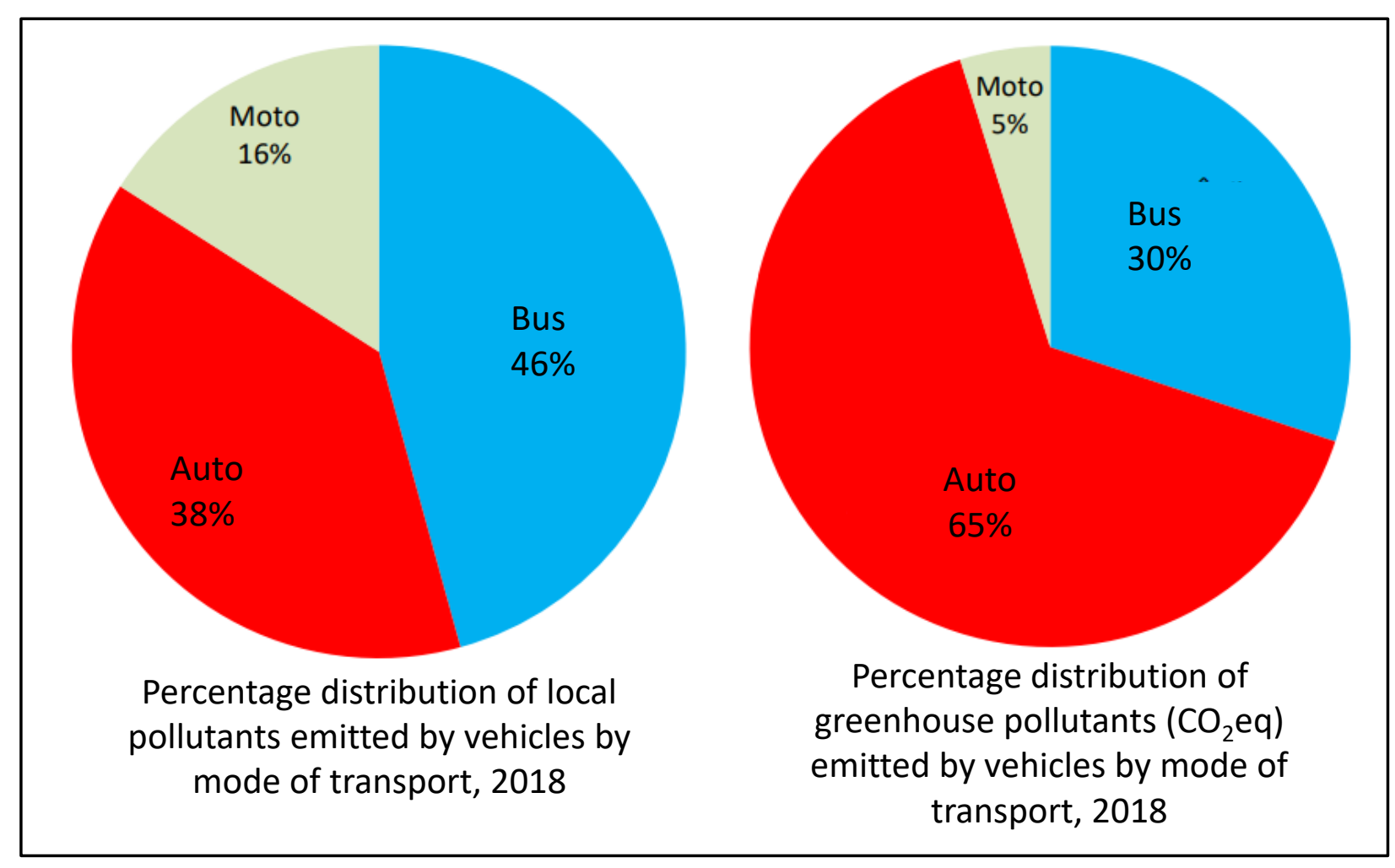

Source: ANTP - “Associação Nacional de Transportes Públicos”, 2018.

Revista ENIAC Pesquisa, Guarulhos (SP), V.9, n.2, ago.- jan. 2020 
The difference between the local pollutants' emissions and the global greenhouse gases emissions are evident. The actions to mitigate are made locally according the sectors that have the high numbers of emissions. Although the reducing emissions local rules are important, they have a weak impact when we look at global results showing that the actions should be done globally (Brunel and Johnson, 2019). The COVID-19 pandemic corroborate the idea in wich a global action will mitigate the emissions, decreasing for $\mathrm{NO}_{x}, \mathrm{CO}, \mathrm{CO}_{2}$ and $\mathrm{SO}_{2}$ as a result of the surface-transport reduction according to levels registered mainly in April (Forster et al, 2020).

\section{METHODOLOGY}

The content produced in this study was made by a massive search at the available literature about fossil fuels and biofuels, as well as the proved effect difference at the air condition and consequently impact in human health. The review was carried out from the Google Scholar search site, Scielo databases, Agência Nacional do Petróleo, Gás Natural e Biocombustíveis, Ministério da Agricultura, Pecuária e Abastecimento, Embrapa, Cetesb and other Electronic Journals, from January 2000 to May 2020, using the following descriptors: biodiesel, fossil fuels, air pollution, health and environment.

\section{ANALYSIS AND DISCUSSION}

\subsection{Biodiesel: production and characteristics}

Brazil, for having an extensive geographical area with a tropical and subtropical climate, contributes to a wide diversity of raw materials for the production of biodiesel, highlighting the vegetable oils from soy, palm, peanut, sunflower, cotton, castor, jatropha and oilseeds, in addition to the use of animal fats or algae oil and oils already used in food frying (Sebrae, SHAHID; JAMAL, 2011; GÜNAY et al., 2019). Biodiesel is a renewable fuel obtained from the mixture of fatty acid esters formed by the methyl transesterification of these oils and catalyzed by a strong base (Figure 4), in addition, there are many important catalytic variables in production, such as metal alkoxides that can be used directly in the reaction medium, in relation to the type and composition of the catalyst and the pre-treatment

Revista ENIAC Pesquisa, Guarulhos (SP), V.9, n.2, ago.- jan. 2020 
conditions, such as temperature, acidity and calcination time (GÜNAY et al., 2019; RAMOS et al, 2011).

Figure 4 - Basic transesterification technology of vegetable oils.

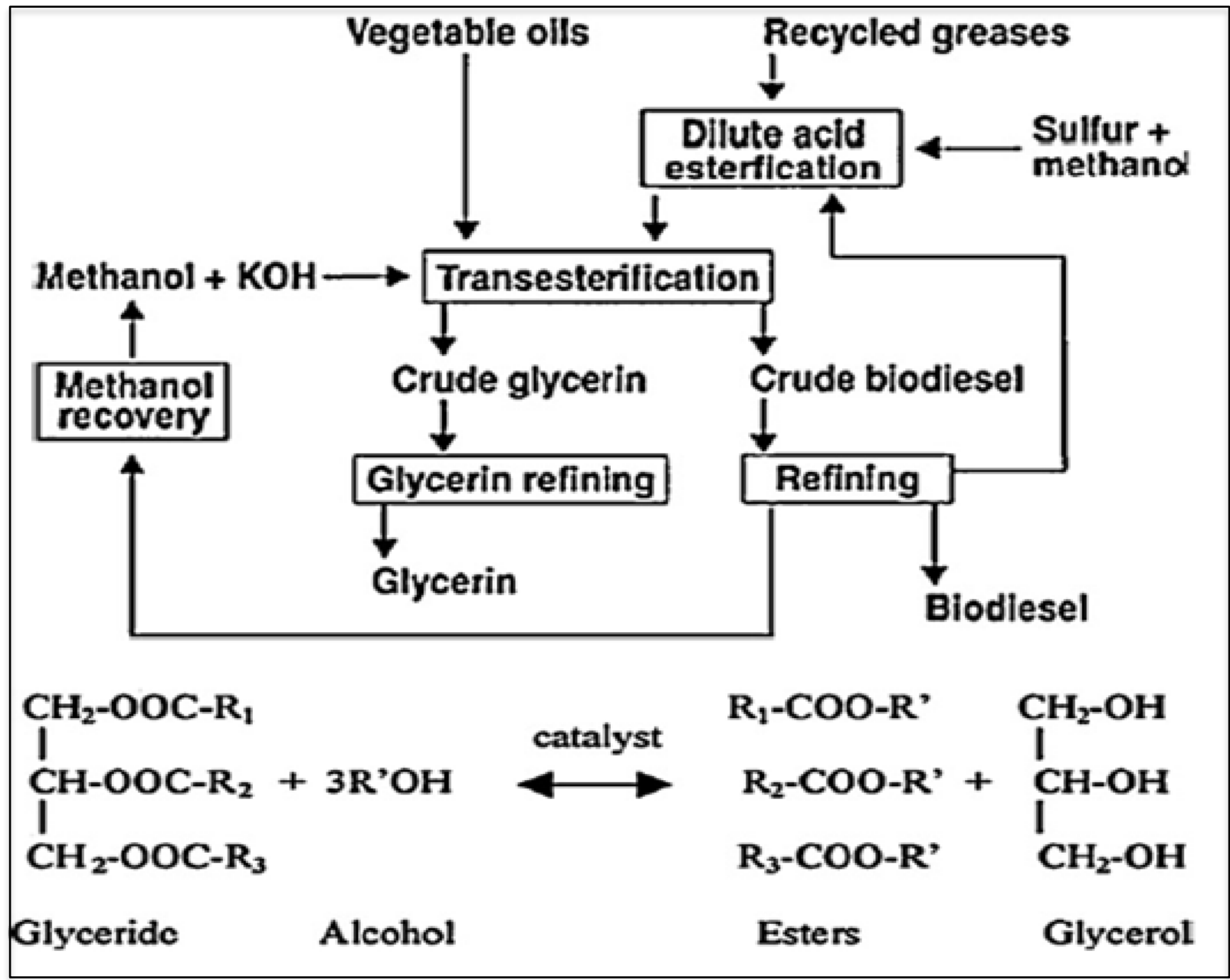

Source: SHAHID and JAMAL, 2011.

Obtaining vegetable oil involves physical-chemical processes on oilseeds, usually by pressing and extracting with solvents. The oil must be previously treated, going through the purification and refining phases in order to remove possible contaminants (SILVA, 2010). The biodiesel production steps involve the preparation of the raw material, followed by the transesterification reaction, phase separation, alcohol recovery and dehydration and, later, purification of esters and glycerin (ENCARNAÇÃO, 2008).

Revista ENIAC Pesquisa, Guarulhos (SP), V.9, n.2, ago.- jan. 2020 
Several characteristics must be taken into account to be analyzed in order to verify the quality of the biofuel produced and must be in accordance with international specifications, to ensure a quality fuel, capable of helping to preserve the environment and guaranteeing consumer's rights. The control of characteristics such as viscosity, flash point, sulfated ash, methanol or ethanol concentration, sodium and potassium salts, free and total glycerol, carbon residues and oxidative stability are extremely important for the conservation and good functioning of the engine, besides of pollutant control (SILVA, 2011).

In this context, biodiesel is essential to guarantee economic and socio-environmental sustainability in society, however, biodiesel derived from oilseeds, frying oils and animal fat does not meet even a small portion of the global demand for biofuels (RAMOS et al. , 2011).

\subsection{Biodiesel: soybean as raw material}

According to Agência Nacional do Petróleo, Gás Natural e Biocombustíveis (ANP, 2020), soybean is the main raw material used in biodiesel production (Figure 5). The process of obtaining biodiesel from soybean oil can achieve conversion rates greater than $97 \%$ of the oil in ethyl esters, through the basic transesterification process.

Brazil is one of the main soybean producers in the world and still has a potential for competitive growth and expansion of production areas throughout the country. In addition, the highest proportion of soybeans grown in the national territory is presented as a genetically modified organism (GMOs), with its main derivatives being grains, bran, and oils (GAVIOLI; NUNES, 2015). However, there may be a negative impact caused by transgenic contamination, since most countries have flaws in a system of responsibility for GMOs, wherein the transgenic costs to avoid such contamination is contaminated by the counter and not by contaminant (FUSCALDI et al., 2012).

Revista ENIAC Pesquisa, Guarulhos (SP), V.9, n.2, ago.- jan. 2020 
Figure 5 - Profile national raw materials consumed to produce biodiesel in Brazil.

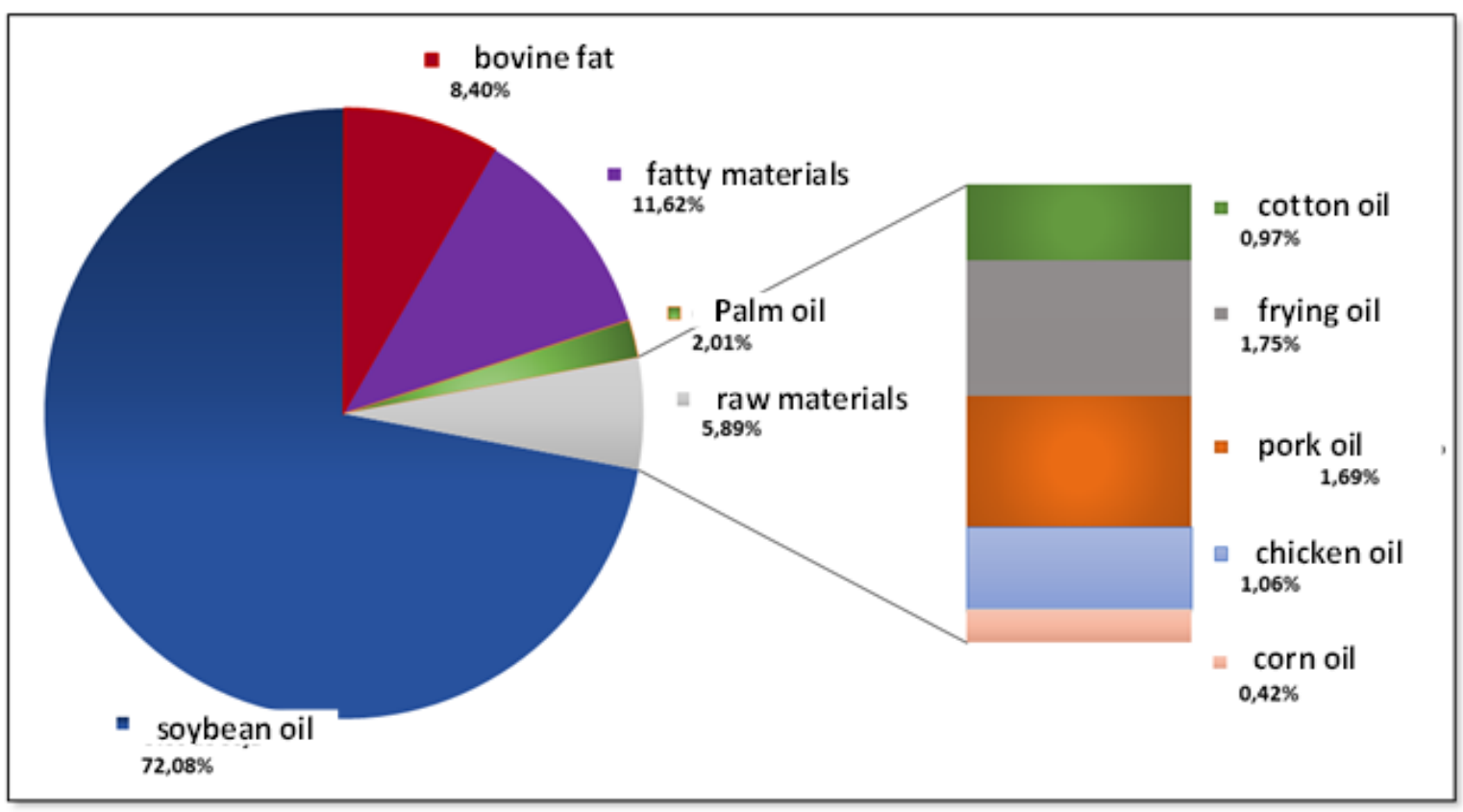

Source: modified from ANP, 2020.

To ensure profitability, soybean cultivation extends over large areas over the Cerrado, Caatinga and Amazon rainforest, causing impacts in important regions of national biodiversity conservation. (SANTILLI, 2009). Furthermore, according to Santilli (2009), the transgenic soybeans cultivation can have a negative impact caused by water and soil contamination by the use of agrochemicals, in addition to desertification and replacement of native forests, since agrobiodiversity systems, which are more sustainable and long-term stable, are replaced by large-scale monocultures with a narrow genetic base.

In Brazil , soybean is the main agrochemical consumer culture, with an alarming perspective considering its agricultural expansion due to transgenic soybean, in second place is sugarcane, however, these crops must be taken into account due to their importance and use for the biofuels production. In addition, health studies indicate that the use of agrochemicals harms the health of consumers of contaminated food, residents of the areas surrounding production areas, communities affected by aerial spray residues and agricultural workers (ARAÚJO; OLIVEIRA, 2016).

Revista ENIAC Pesquisa, Guarulhos (SP), V.9, n.2, ago.- jan. 2020 


\subsection{Air pollutants and health effects}

The effects of air pollution can be classified according to their acute effects, which may have temporary effects, generally reversible and occur when adverse weather conditions causing eye irritation, coughing, and when the effects are more severe lead to death. Chronic effects are permanent, causing loss of visibility, damage to vegetation and public health (MANZOLI, 2009).

The main atmospheric pollutants are - i.) Sulfur dioxide $\left(\mathrm{SO}_{2}\right)$, resulting from the diesel burning resulting from the diesel burning, industrial oil and gasoline, which when oxidized gives rise to sulfuric acid $\left(\mathrm{H}_{2} \mathrm{SO} 4\right)$ (CETESB, 2012). According to Instituto Nacional do Meio Ambiente do Rio de Janeiro (INEA), $\mathrm{SO}_{2}$ causes irritation in the respiratory tract, cough, and breathlessness. Aggravating the symptoms of asthma and chronic bronchitis, as well as affecting sensory organs. ii.) Carbon monoxide (CO), result of the incomplete organic fuel burning, fossil fuels and biomass are emitted mainly in areas with intense vehicles circulation (CETESB, 2012). Exposure to $\mathrm{CO}$ is associated with decreased oxygen carrying capacity in the blood (CLEVA; LAUDANNA, 2007). iii.) Nitrogen monoxide (NO) and nitrogen dioxide $\left(\mathrm{NO}_{2}\right)$, vehicles are the main emitters of these gases. NO, under the action of sunlight, becomes $\mathrm{NO}_{2}$, which plays an important role in the formation of photochemical oxidants such as ozone. Depending on the concentrations, $\mathrm{NO}_{2}$ causes damage to health, causing eyes, nose, and throat irritation (CETESB, 2012). iv.) photochemical oxidants is the name given to the mixture of secondary pollutants formed by the reactions between nitrogen oxides and volatile organic compounds, in the presence of sunlight, being released in burning and evaporation incomplete of fuels and solvents. Such pollutants form photochemical haze causing decreased visibility. Atmospheric ozone acts as an ultraviolet sun filter (CETESB, 2012). However, the closer to the Earth's surface, the more harmful it will be to health, which may cause lipids ozonation/peroxidation in the fluid of lung epithelial lining (RUNGE; GREGANTI, 2010). v.) Hydrocarbons are compounds formed by carbon and hydrogen atoms. Petroleum and its derivatives such as cooking gas, gasoline, kerosene and diesel oil are constituted by hydrocarbons (SILVEIRA, 2020). These compounds are carcinogenic and mutagenic, with no totally safe environmental concentration (CETESB, 2012). vi.) Total and inhalable particulate

Revista ENIAC Pesquisa, Guarulhos (SP), V.9, n.2, ago.- jan. 2020 
matters are not a defined chemical species, but of particles set that include dust, powders, fumes and aerosols emitted to the atmosphere (TORRES et al., 2008). According to CETESB (2012), the particle size is inversely to the potential damage to health. Total particulate matters, when inhaled, can cause health problems, and impair quality of life, interfering with the aesthetics of the environment and impairing the community's usual activities. Inhalable particulate matters are particles that can be retained in the respiratory system and reach the pulmonary alveoli, being harmful when deposited in any respiratory tract region (BLEVIGLIERO, et al. 2006).

\subsection{Biodiesel $x$ Air pollution}

Mixing biodiesel with diesel leads to significant decreases in pollutant emissions, including $\mathrm{CO}$, sulfates, and particulate matters, which are compounds that are harmful to respiratory health, aggressors of the environment and cancer-causing. The reductions in pollutant levels are proportional to the increase in the percentage of biodiesel added to the mixture (5\%, 10\% and 20\%, B5, B10 and B20, respectively), as we can see at the Figure 6.

Figure 6 - Pollutant emissions according to the percentage of biodiesel added to fossil diesel.

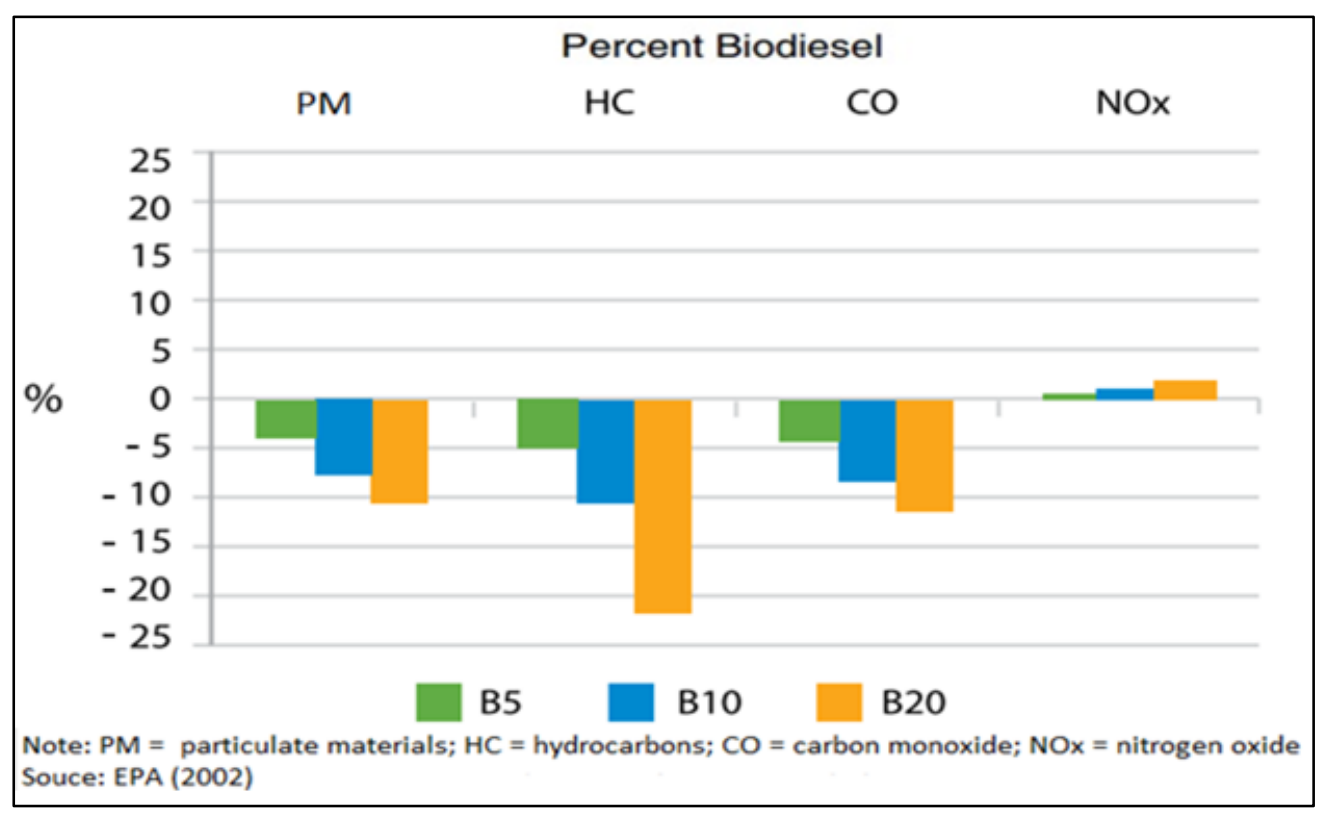

Sources: modified from MAPA, 2014.

Revista ENIAC Pesquisa, Guarulhos (SP), V.9, n.2, ago.- jan. 2020 
Biodiesel increasing brings significant progress in $\mathrm{CO}$, hydrocarbons and particulate matters emissions; however, it promotes a small increase in nitrogen oxide $\left(\mathrm{NO}_{\mathrm{x}}\right)$ emissions. However, the possibility of minimizing $\mathrm{NO}_{\mathrm{x}}$ emissions occurs mainly in engine parameters calibration, such as the injected volume, start and injection pressure (SALA; JÚNIOR, 2006; MAPA, 2014).

For Equipe de Pesquisa Energética (EPE, 2005), by mixing biodiesel from soy in proportions of $5 \%$ in diesel, it is possible to achieve reductions greater than $4 \%$ in the levels of $\mathrm{CO}_{2}$ emissions. And, according to the 2019 ANP statistical yearbook (2020), biodiesel production grew $24.7 \%$ in 2018 , due to the increase in the content of diesel blends from $8 \%$ to $10 \%$, according to Law No. 13,163/2016. This in turn provides better rates in reductions in emissions.

In the Air Quality Report issued by Cetesb (2018), it is possible to observe a continuous drop in the air pollutants values emitted by motor vehicles in the period from 2006 to 2017 (Figure 7), motivated mainly by the vehicles incorporation with new technologies in replacement old and more polluting vehicles. The most significant reduction was in relation to $\mathrm{SO}_{2}$, with a sharp drop in 2014 due to the change in sulfur diesel content from 2013 and of gasoline in 2014.

Figure 7 - Vehicle pollutant emissions evolution in São Paulo State.

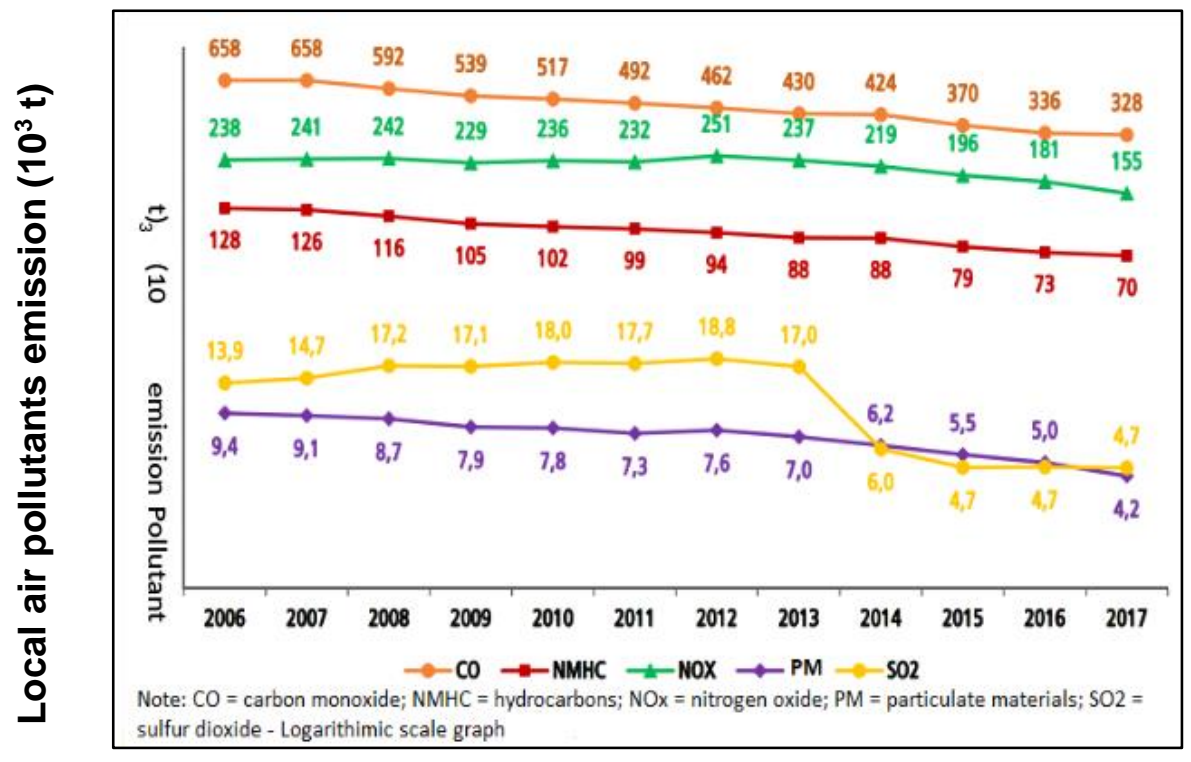

Source: modified from CETESB, 2018.

Revista ENIAC Pesquisa, Guarulhos (SP), V.9, n.2, ago.- jan. 2020 
Furthermore, the MAPA study (2014) provided a comparative reduction in greenhouse gas levels and the equivalent value of trees planted per year, where every percentage over mandatory biodiesel in Brazil, equivalent to planting nearly 7.2 million trees (Figure 8).

Air pollution has been a serious problem in urban center communities, in which research indicates that the most affected systems due to this pollution are respiratory, circulatory, and reproductive (VIGIAR). The WHO together with the International Cancer Research Agency (IARC) reported in 2013 that air pollution should be considered an environmental cause of cancer deaths. In addition, data from IARC showed that in 2010, more than 223,000 people died from lung cancer related to air pollution (ANDRÉ et al. 2017).

Between 2006 and 2011, the Instituto de Saúde e Sustentabilidade evaluated environmental data on air pollution in São Paulo State, where found that the annual averages of inhalable particulate matters were 2 to 2.5 times higher than the standards recommended by WHO $\left(10 \mu \mathrm{g} / \mathrm{m}^{3}\right)$, which can be assigned during the years of study, 99,084 deaths related to air pollution in São Paulo State (ANDRÉ et al. 2017).

\section{Figure 8 - Greenhouse gas emissions avoided and equivalence in plantations of trees} per year considering the different percentages of mixing biodiesel in diesel.

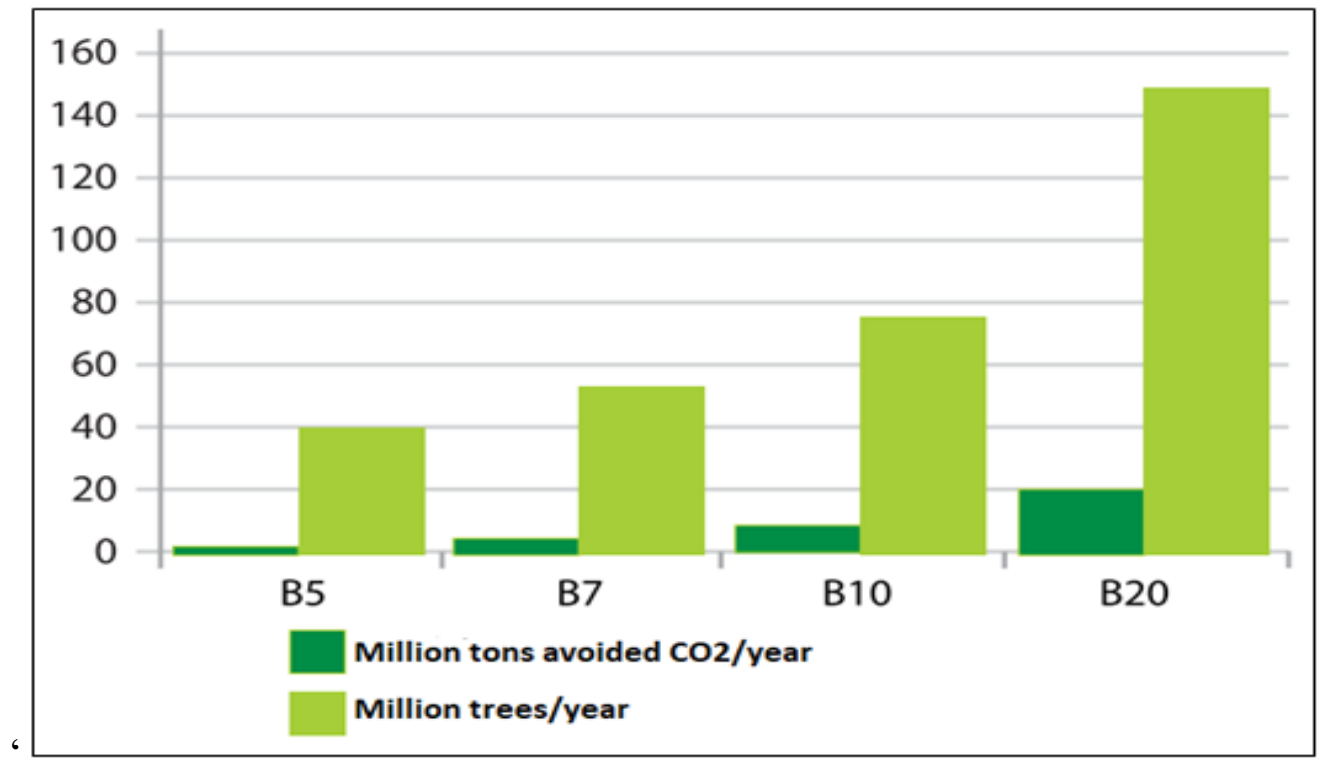

Source: modified from MAPA, 2014.

Revista ENIAC Pesquisa, Guarulhos (SP), V.9, n.2, ago.- jan. 2020 
According to Amâncio and Nascimento (2012), atmospheric pollutants associated with chronic diseases in children and increases in the risk of death are mainly particulate matters and $\mathrm{SO}_{2}$, mainly because they are respiratory irritants capable of being deposited in the upper respiratory tract and lung parenchyma. Furthermore, Nardocci et al. (2013) showed a relationship between air particulate matter concentrations and ozone accumulation respiratory diseases in children under 5 years old and cardiovascular diseases in adults over 39 years old.

High concentrations of air particulate matters can have effects that go beyond cardiorespiratory diseases, as evaluated by Romão et al. (2013), particulate matter and $\mathrm{SO}_{2}$, might present a risk in the first trimester of pregnancy, due to the increased risk of low birth weight newborns. As well, according to Lima et al. (2014), the exposure of pregnant women to particulate matters can trigger premature births both on the day and up to three days after the mother is exposed to these pollutants. Reinforcing the concept that air pollution influences pregnancy outcomes. However, Santos et al. (2014) did not obtain statistically significant results for weight reduction in babies at birth associated with pollutants, but with the exception of $\mathrm{SO}_{2}$, which in the last month of pregnancy can be associated with up to 1.25 times more chance for low birth weight newborns (OR 1.25; 95\% CI 1.00-1.56) in the last month of maternal exposure.

According to André et al. (2012), the delay in implementation of clean policies would lead to almost 14,000 deaths by 2014 with over 18,000 hospitalizations in the public health system in different metropolitan regions. Besides that, urban pollution has negative health effects with worsening respiratory diseases, negative effects on pregnancy and fetal development with an increase in hospitalizations and medicines use in regions with air pollution moderate or high levels. Even though the increase in motorized transport is a positive indicator for the economy, it is accompanied by environmental and social challenges that affect the health and population well-being.

\section{CONCLUSION}

The fossil fuels use contributes for air pollution increase due to emissions of $\mathrm{CO}_{2}$,

Revista ENIAC Pesquisa, Guarulhos (SP), V.9, n.2, ago.- jan. 2020 
$\mathrm{SO}_{2}$, particulate matters and hydrocarbons, in view that the pollutants excess proves to be harmful to human health and the environment. Losses in quality of life, increase in hospital admissions result from diseases associated with air pollution. Moreover, we can say that biodiesel is an admirable alternative for mitigating emissions of greenhouse gases, being an important source of biofuel as innovations in energy matrices, it is advantageous in reducing particulate matters emissions and other compounds harmful to human health, in addition to promoting an improvement in air quality.

\section{REFERENCES}

AMÂNCIO, C.T.; NASCIMENTO, L.F.C. Asma e poluentes ambientais: um estudo de séries temporais. Revista da Associação Médica Brasileira, 58: 302-307. 2012.

ANDRÉ, P.A.; VERAS, M.M.; MIRAGLIA, S.G.E.K.; SALDIVA, P.H.N. Lean diesel technology and human health: a case study in six Brazilian metropolitan regions. Clinics. 6: 639-645. 2012.

ANDRÉ, P.A.; VORMITTAG, E.M.P.A.A.; SALDIVA, P.H.N. Impactos da poluição do ar na saúde da população decorrente da substituição da matriz energética do transporte público na cidade de São Paulo. Instituto Saúde e Sustentabilidade e Greenpeace. 2017. Disponível em: $\quad$ https://www.saudeesustentabilidade.org.br/wpcontent/uploads/2017/05/GP_ISS_Relatorio_ImpactosOnibusSP-1.pdf $>$ acesso em: 01 Maio 2020

ARAÚJO, I.M.M.; OLIVEIRA, A.G.R.C. Agronegócio e agrotóxicos: impactos à saúde dos trabalhadores agrícolas no nordeste brasileiro. Trabalho, Educação e Saúde, 15: 117-129. 2016.

ASSOCIAÇÃO NACIONAL DE TRANSPORTES PÚBLICOS (ANTP). Sistema de informações da mobilidade urbana da associação nacional de transportes público SIMOB/ANTP. Relatório geral 2018. Maio de 2020. Disponível em: 〈http://files.antp.org.br/simob/sistema-de-informacoes-da-mobilidade--simob--2018.pdf> acesso em: 27 Outubro 2020.

BENEFÍCIOS AMBIENTAIS DA PRODUÇÃO E DO USO DO BIODIESEL. Ministério da Agricultura, Pecuária e Abastecimento (MAPA). 2014. Disponível em: <https://www.bsbios.com/media/adminfiles/relatorio_biodiesel_p_web.pdf $>$ acesso em: 05 Maio 2020

Revista ENIAC Pesquisa, Guarulhos (SP), V.9, n.2, ago.- jan. 2020 
BIODIESEL. Serviço Brasileiro de Apoio às Micro e Pequenas Empresas (SEBRAE).

Disponível em:

<https://www.agencia.cnptia.embrapa.br/Repositorio/NT00035116_000gihb7tn102wx5ok05

vadr1szzvy3n.pdf> acesso em: 01 Maio 2020.

BLEVIGLIERO, E.; POSSEBON, J.; SPINELLI, R. Higiene Ocupacional: Agentes Biológicos, Químicos e físicos. São Paulo/SP. 8ª ed. Senac-SP. 2006.

BRUNELA, C.; JOHNSON, E.P. (2019). Two birds, one stone? Local pollution regulation and greenhouse gas emissions. Energy Economics. v. 78, p. 1-12, 2019.

CARVALHO, C.H.R. Emissões relativas de poluentes do transporte motorizado de passageiros nos grandes centros urbanos brasileiros. Instituto de Pesquisa Econômica Aplicada. 2011. Disponível em: <https://www.econstor.eu/bitstream/10419/91332/1/664398472.pdf> acesso em 26 Outubro 2020

CLEVA, R.; LAUDANNA, A. Diagnóstico e Tratamento. São Paulo/SP. Ed: Manole ltda. 2007.

DERISIO, J.C. Introdução ao controle de poluição ambiental. São Paulo: Oficina de textos, 2013.

ENCARNAÇÃO, A.P.G. Geração de biodiesel pelos processos de transesterificação e hidroesterificação, uma avaliação econômica. Dissertação (Mestrado em Ciências). Universidade Federal do Rio de Janeiro. Rio de Janeiro/RJ. 2008.

Forster, P.M., Forster, H.I., Evans, M.J. et al. Current and future global climate impacts resulting from COVID-19. Nat. Clim. Chang. v. 10, p. 913-919, 2020.

FUSCALDI, K.C.; MEDEIROS, J.X.; PANTOJA, M.J. Soja convencional e transgênica: percepção de atores do SAG da soja sobre esta coexistência. Revista de Economia e Sociologia Rural, v. 49, p. 991-1020, 2012.

GAVIOLI, A.P.R.; NUNES, J.S. A soja transgênica no Brasil e suas influências à saúde e ao meio ambiente. Revista Científica da Faculdade de Educação e Meio Ambiente, v. 6, p. 1$16,2015$.

GÜNAY, M.E.; TÜRKER, L.; TAPAN, N.A. Significant parameters and technological advancements in biodiesel production systems. Fuel, v. 250, p, 27-41, 2019.

LIMA, T.A.C.; NASCIMENTO, L.F.C.; MEDEIROS, A.P.P.; SANTOS, V.P. Association between maternal exposure to particulate matter and premature birth. Revista Ambiente \& Água - An Interdisciplinary Journal of Applied Science, v. 9, p. 27-36, 2014.

MANZOLI, A. Análises das emissões veiculares em trajetos urbanos curtos com localização por GPS. Tese (Doutorado) - Universidade de São Carlos, SP, 2009.

Revista ENIAC Pesquisa, Guarulhos (SP), V.9, n.2, ago.- jan. 2020 
NARDOCCI, A.C.; FREITAS, C.U.; LEON, A.C.M.P.; JUNGER, W.L.; GOUVEIA, N.C. Poluição do ar e doenças respiratórias e cardiovasculares: estudo de séries temporais em Cubatão, São Paulo, Brasil. Caderno de Saúde Pública, v. 29, p. 1867-1876, 2013.

Outdoor air pollution a leading environmental cause of cancer deaths. IARC - International Agency for Research on Cancer. Lyon: WHO, 2013. Disponível em: <https://www.iarc.fr/wp-content/uploads/2018/07/pr221_E.pdf> Acesso em 05 Maio 2020.

PERFIL NACIONAL DE MATÉRIAS-PRIMAS CONSUMIDAS PARA PRODUÇÃO DE BIODIESEL. Agência Nacional do Petróleo, Gás Natural e Biocombustíveis (ANP 2020). Disponível em: <http://www.anp.gov.br/producao-de-biocombustiveis/biodiesel/informacoesde-mercado> Acesso em 02 Maio 2020.

POTENCIAL DE REDUÇÃO DE EMISSÕES DE CO $\mathrm{CO}_{2}$ EM PROJETOS DE PRODUÇÃO E USO DE BIOCOMBUSTÍVEIS. Empresa de Pesquisa Energética (EPE, 2005). Disponível em: $\quad\langle$ http://www.epe.gov.br/sites-pt/publicacoes-dadosabertos/publicacoes/PublicacoesArquivos/publicacao-250/topico-304/EPE\%20-

\%202\%C2\%BA\%20Biocombust\%C3\%ADveis\%20x\%20MDL[1].pdf> acesso em: 05 Maio 2020

QUALIDADE DO AR NO ESTADO DE SÃO PAULO [eletronic resource]. Companhia Ambiental do estado de São Paulo (CETESB, 2012) Disponível em: <https://cetesb.sp.gov.br/wp-content/uploads/2019/07/Cetesb_QualidadeAr_2012R.pdf>

Acesso em 05 Maio 2020.

QUALIDADE DO AR NO ESTADO DE SÃO PAULO [recurso eletrônico]. Companhia Ambiental do estado de São Paulo (CETESB, 2018) Disponível em: 〈https://cetesb.sp.gov.br/wp-content/uploads/2019/07/Cetesb_QualidadeAr_2018R.pdf> Acesso em 05 Maio 2020.

QUALIDADE DO AR. Ministério do Meio Ambiente (MMA). Disponível em: <https://www.mma.gov.br/cidades-sustentaveis/qualidade-do-ar.html > acesso em: 01 Maio 2020 .

RAMOS, L.P.; DA SILVA, F.R.; MANGRICH, A.S.; CORDEIRO, C.S. Tecnologias de produção de biodiesel. Revista Virtual de Química, v. 3, p. 385-405, 2011.

RESENHA ENERGÉTICA BRASILEIRA. Oferta e demanda de energia, instalações energéticas, energia no mundo. 2020. Disponível em:

<http://www.mme.gov.br/web/guest/secretarias/planejamento-e-desenvolvimentoenergetico/publicacoes/resenha-energetica-brasileira> acesso em:26 Outubro 2020.

ROMÃO, R.; PEREIRA, L.A.A.; SALDIVA, P.H.N.; PINHEIRO, P.M.; BRAGA, A.L.F.; MARTINS, L.C. The relationship between low birth weight and exposure to inhalable particulate matter. Caderno de Saúde Pública, v. 29, p. 1101-1108, 2013.

Revista ENIAC Pesquisa, Guarulhos (SP), V.9, n.2, ago.- jan. 2020 
RUNGE, M.S.; GREGANTI, M. Netter Medicina Interna. São Paulo/SP. $2^{a}$ ed. Elsevier Health Sciences, 2010.

SALA, R.C.; JÚNIOR R.G.M. Análise comparativa entre diesel e biodiesel. Dissertação (Graduação em Engenharia Mecânica). Universidade Federal do Espírito Santo. Vitória - ES, 2006.

SALLET, C.L.; ALVIN, A.M. Biocombustíveis: uma análise da evolução do biodiesel no Brasil. Economia \& Tecnologia, v. 27, p. 1-13, 2011.

SANTILLI, J.F.R. Agrobiodiversidade e direitos dos agricultores. Tese (Doutorado em Direito). Pontifícia Universidade Católica do Paraná. Curitiba/PR. 2009.

SANTOS, V.P.; MEDEIROS, A.P.P.; LIMA, T.A.C.; NASCIMENTO, L.F.C. O papel dos poluentes atmosféricos sobre o peso ao nascer em cidade de médio porte Paulista. Revista Paulista de Pediatria, v. 32, p. 306-312, 2014.

SHAHID, E.M.; JAMAL, Y. Production of biodiesel: A technical Review. Renewable and Sustainable Energy Reviews, v. 15, p. 4732-4745, 2011.

SILVA, N.L. Produção de biodiesel: processo e caracterizações. Tese (Doutorado em Engenharia Química) - Faculdade de Engenharia Química da Universidade Estadual de Campinas, Campinas/SP, 2010.

SILVA, T.A.R. Biodiesel de óleo residual: produção através da transesterificação por metanólise e etanólise básica, caracterização físico-química e otimização das condições reacionais. Tese (Doutorado em Química) - Universidade Federal de Uberlândia, Uberlândia/MG, 2011.

SILVEIRA, I.B. Produção de Biodiesel. São Paulo/SP. Biblioteca 24horas.com. 2020.

SOLIANI, R.D.; ARGOUD, A.R.T.T. A emissão de gases poluentes no transporte rodoviário de cargas brasileiro. Revista Espacios, v. 39, p. 14. 2018

SOUZA, V.H.A.; SANTOS, L.T.; CAMPOS, A.F., CAROLINO, J. Um panorama do biodiesel no Brasil e no mundo: esforços para a ampliação do setor e desafios. Revista Augustus, v. 21, p. 11-130, 2016.

SPIRO, T.G.; STIGLIANI, W.M. Química ambiental. São Paulo: Pearson, 2009.

TESTA, J.F. A poluição atmosférica por veículos automotores na região metropolitana de São Paulo: causas e impactos. Revista Eletrônica em Gestão, Educação e Tecnologia Ambiental, v. 19, p. 1209-1221, 2015.

TORRES, P.T.F.; ROCHA, C.G; RIBEIRO, A.G. (organizadores). Geociências Aplicadas: diferentes abordagens. Ubá /MG. Geographica, consultoria, estudos e projetos ambientais ltda, 2008.

Revista ENIAC Pesquisa, Guarulhos (SP), V.9, n.2, ago.- jan. 2020 
VIGIAR. Vigilância em Saúde de Populações Expostas a Poluição Atmosférica. Disponível em: 〈https://www.saude.gov.br/vigilancia-em-saude/vigilancia-ambiental/vigiar> acesso em:01 Maio 2020.

Revista ENIAC Pesquisa, Guarulhos (SP), V.9, n.2, ago.- jan. 2020 